\title{
Medicine in New Guinea: three and a half centuries of change
}

\author{
C. R. B. BlackBurn \\ M.D., F.R.C.P., F.R.A.C.P. \\ Department of Medicine, University of Sydney, \\ Sydney, New South Wales 2006, Australia
}

In 1502, Ludovico di Varthema set out from Italy, joined a Persian merchant and sailed to India and then through the Straits of Malacca to the Moluccas, the Spice Islands and Java, returning to India in 1506 when the Portuguese had just defeated the Arabian fleet. In Calicut he told three Portuguese captains who were friends, Antonio d'Abreu, Francisco Serrano and Ferdinand Magellan, about the Spice Islands.

D'Abreu and Serrano after the conquest of Malacca in 1511-12 sailed to the Moluccas. They then coasted New Guinea, but did not land, and seem to be the first Europeans to see it although the Chinese and Malays knew New Guinea at least from the eighth century.

Serrano wrote of his discoveries of the Spice Islands to his friend Magellan, now in Portugal, who set out in 1519 to find a shorter way to these islands. Balboa had seen the Southern Ocean from Darien in 1513 and Magellan, commanding five Spanish ships, sailed through the straits named after him across the Pacific to the Philippine Islands where he was killed by the natives. His ships sailed back to Spain via the Cape of Good Hope after calling at the Moluccas.

In 1526 Jorge de Meneses, Portuguese governor of the Moluccas, landed at Warsai on the north-west coast of New Guinea to wait for favourable winds. He called the country 'Ilhas dos Papuas', a name derived from the Malay term 'papuwah' meaning frizzy-haired men-420 years later the Australian soldiers were grateful for the help of the people they called 'fuzzy-wuzzies'.

The Spaniard, Alvaro de Saavedra, attempting to return to Mexico from the Moluccas, spent a month on the coast of the islands 'de los Crespos' in 1528. In 1545, Ynigo Ortiz de Retes returning to Mexico gave the name Nueva Guinea to the island because it resembled Guinea.

On 21 December 1605 de Quiros, commanding the San Pedro y San Pablo, the 60 tons flagship captained by Don Diego de Prado, and Luis Vaez de Torres in the smaller 40 tons ship, the San Pedrico, sailed from
Peru for the west. When mutiny threatened after a landing at Espiritu Santo in the New Hebrides, de Quiros and his ship turned back, but de Prado and others transferred to Torres' ship and visited the Louisade Archipelago, Doini Islands, Bona Bona and other islands and went on to the Philippines. They sailed along the southern coast of New Guinea because of adverse winds and passed through the strait between Australia and New Guinea which was named after Torres. The details of this voyage were lost for 150 years.

Diego de Ribera was surgeon on Torres' ship and was joined by Alonso Sanchez de Aranda of Seville, surgeon and doctor, who, with de Prado, transferred from the flagship before de Quiros turned back. They appear to have been the first doctors to visit New Guinea and the nearby islands. It is hard to believe that they failed to go ashore on any of the numerous landings for water and food described by de Prado.

In 1642, Abel Janssen Tasman left Batavia, discovered Tasmania (Van Diemen's Land) and New Zealand and then sailed back to Batavia, passing along the coast of New Guinea and between it and Jilolo Island. He had on his ship Henrick Haalbos, the 'wound healer', a barber-surgeon, but there seems to be no record of his landing.

William Dampier in the leaky, rotting Roebuck discovered and explored New Britain and sailed along the north coast of New Guinea which he first saw on New Year's Day 1700. William Borthwick, a surgeon, was with him and surely was on shore on some of the occasions they sought food and water and collected flora and fauna-for example at Mackerel Bay and Freshwater Bay in New Guinea. Dampier did not seem impressed with his surgeon and he wrote the 'other officers, including the master, two mates, gunner and surgeon were a colourless lot'.

Philip Carteret, sailing round the world in 1766-69, took with him Thomas Watson, surgeon, and anchored on the south-east coast of New Ireland where he carried out formal acts of possession after visiting 
New Britain. Eleven months later, Louis de Bougainville entered what he called Port Praslin in New Ireland and found the remains of Carteret's plaque and he stayed there for 2 weeks in July 1768.

de Bougainville circled the world and discovered the island that bears his name in the frigate $L a$ Boudeuse. He had with him le Porte, surgeon, and, on the store ship l'Etoile, Vivez, also a surgeon. M. M. de Commerçon was the physician for the expedition and landed with Bougainville on various islands including New Guinea: no doubt the surgeons also landed.

Captain James Cook had with him in the Endeavour William Broughton Monkhouse, surgeon, William Perry, surgeon's mate, and Daniel Carl Solander, physician-naturalist, who provides a special link between Captain Cook, Australia, and New Guinea.

Carl Solander, born in 1733 in Sweden, was trained by and became a friend of Carl Linnaeus, the botanist who introduced a system of classification which made botanical collecting worthwhile. Linnaeus also graduated in medicine and was, for a time, physician to the Swedish Admiralty. It is not surprising that many of his students not only graduated in medicine to become physician-naturalists but also took posts in ships. Solander became a close friend of Joseph Banks on the voyage and in August 1770, at De Jong's point, New Guinea, Joseph Banks records in his diary 'The Captain, Dr Solander and myself with the boats crew and my servants' went ashore. Their visit was short because natives appeared and behaved in a hostile manner.

In 1791, John McCluer visited the north and west coast of New Guinea and found nutmeg growing there. His stories fired the imagination of Captain John Hayes of the British East India Company and he established the first European colony, Fort Coronation, at Dorei Bay in 1793 and took possession of the Island of New Guinea for King George III without authority. His act was repudiated. In 1795 the survivors of the fourteen Europeans and eleven Lascars and Sepoys who were originally left by Hayes were evacuated to Ceram.

Dutch Government and various missionary settlements in different parts of New Guinea between 1828 and 1864 were abandoned after decimation by disease and the natives. None of these settlements seem to have had doctors.

For the next 120 years most medical visits were transitory and based on curiosity and exploration rather than on providing medical care for the native population. Many doctors were physician-naturalists in the Linnaean tradition or naval surgeons. Bruny d'Entrecastreux, in 1791, searching for La Perouse, lost years before, visited the islands round New Guinea and had with him Claude Riche, a 'mild and sickly' doctor and botanist, and Jaques Julien de la
Billardière, a 35-year-old botanist and doctor, a 'prickly republican' who had gone to England to examine Sir Joseph Banks' botanical collection before setting out for the Pacific Islands. Dumont d'Urville in the Astrolabe explored New Ireland and other islands in 1827 and carried Joseph Paul Grimard, staff surgeon and naturalist, and Pierre Adolph Lessen, surgeon, second grade. In 1854, Thomas Henry Huxley, an assistant to Dr Thomson, naval surgeon, accompanied Captain Owen Stanley in H.M.S. Rattlesnake to survey the Great Barrier Reef and New Guinea. Huxley was exasperated when Owen Stanley refused to let him land on New Guinea and, as a result of the voyage, left the navy, left medicine and became a biologist.

The first white settler-explorer on the north coast of New Guinea was Nicolai Nicolaevitch MiklouhoMaclay born in 1846 in Russia of Scots-Russian descent. He studied jurisprudence and philosophy in Heidelberg, medicine at Leipzig, and natural science and comparative anatomy in Jena but he did not graduate in medicine. Except for a servant, he stayed alone at Astrolabe Bay for 15 months in 1871-72, at Triton Bay on the south-west coast in 1872 , and again at Astrolabe Bay in 1876. He explored the Finisterre range and collected data on the fauna and on the social organization of the natives, but later lost most of his records. He died aged 42, having persuaded the N.S.W. Government to establish a Marine Biological Station in Sydney Harbour and having fought to have the importation of native labour into Australia abolished.

Captain Robert Towns came to Australia in 1842, married the sister of William Charles Wentworth, who was largely responsible for the founding of Sydney University, and became a wealthy squatter and ship owner in Queensland. His name is perpetuated at Townsville, in North Queensland, and his piety led him to give the carved pulpit adorning St Andrews Cathedral in Sydney. He planted cotton in Queensland and, failing to import cheap Indian labour, sent his schooner Don Juan to get islanders from the New Hebrides in 1865.

By September 1866 Towns had imported 315 'kanakas' as cheap labour, a practice known as 'black birding' since many were kidnapped. The treatment of the kanakas was most inhumane and many failed to return to their native islands alive.

Dr James Patrick Murray of Melbourne, L.R.C.S. of Dublin and lately resident physician in Invercargill, New Zealand, had joined the search for Burke and Wills in 1861 and then for Leichhardt in 1865. Medicine was clearly too dull for him so he bought the brig Carl of 256 tons in 1871, did not pay for it, but sailed from Melbourne to Fiji with six passengers. He dropped off two with whom he quarrelled at Tanna in the New Hebrides where they 
were eaten. He kidnapped natives by sinking their canoes and once, when some of his captives on board rioted, he bored holes in the bulwark and shot seventy of them dead, as sport.

Archibald Watson, born in New South Wales on 27 July 1849, became Professor of Anatomy in Adelaide University in $\mathbf{1 8 8 5}$, having graduated in medicine at Göttingen on 10 August 1878. Though intended for the Church, after leaving school when his mother died and his father remarried, he went to the Pacific Islands where he acquired property. He met and sailed as a deck-hand with the infamous Dr Murray on the Carl and it was Watson's admiration for Murray that directed him into medicine so he left the islands in 1872 to take a devious route to Europe.

The kanaka trade was large-in 1881-83, 11,059 islanders were brought to Queensland for the sugar industry, and the Age newspaper sent a young reporter, George Ernest Morrison born in 1862, to investigate. Morrison had failed his second year medical examinations shortly before and went, in 1882 , to Mackay where he signed on as a member of the crew of the Lavinia, a black-birding ship partly owned by Dr Robert McBurney, the local Health Officer. In an attempt to end the practice, Morrison, still very young, wrote some ineffective articles but the traffic only ended in 1901 when a bounty was paid for sugar produced without native labour.

After an attempt by Queensland to annex New Guinea for Britain, the Melbourne Age decided to send an expedition to cross New Guinea. Morrison led it at the age of 21 , but was completely inexperienced, knew nothing of leadership and, because of his incompetence, was speared a few miles from the starting point.

Morrison was ultimately sent to Edinburgh for surgical treatment by Professor John Chiene, finished his medical course in 1887 and after a while in the United States, West Indies, Spain and Morocco, he was resident surgeon in Ballarat Hospital, Victoria, from 1890 to 1892 . He spent most of the next 19 years in China as a newspaper correspondent and adviser to Chinese governments-and became world famous as 'Chinese or Peking Morrison'.

There was no resident doctor in New Guinea at this time but in 1879-81 two French doctors, Dr Goyon and Dr Baudouin, were at Port Breton in New Ireland. The Marquis of Ray had deceived four shiploads of Italians and French into paying to go to colonize Port Breton but sickness and starvation decimated them.

In 1874, the Reverend W. G. Lawes and his wife arrived in Port Moresby, established a mission for the London Missionary Society in which he stayed
21 years, were responsible for all medical care and reduced the local language, Motu, to a written form. In 1877 he was joined by the Rev James Chalmers who explored widely. The missionaries did what they could medically. The Rev Lawes wrote in the Australasian Medical Gazette of 1887 that he 'had almost the sole medical care of the mission' and remarked that half of the South Sea islanders coming with him died of fever, phthisis and other illnesses, that two of the five white women had died, all of the white men had fever and some had died.

During this phase of New Guinea's history Britain recognized the Dutch claim to the western end of New Guinea in 1824; an Australian explorer tried, unsuccessfully, to annex eastern New Guinea for Britain in 1846; the Dutch took possession of West New Guinea in 1848; an Australian company sought a charter to colonize but was refused in 1867 and the New South Wales and Victorian governments pressed Britain to annex New Guinea in 1874 but were refused when they were not prepared to pay the costs. In 1880-83, the German Company Deutsche Seehandelgesellschaft established eighteen trading stations in New Britain and because of this, in 1883, the Premier of Queensland, Thomas McIlwraith, ordered Mr H. M. Chester to go from Thursday Island and to annex Eastern New Guinea and the nearby islands for the Queen, which he did on 4 April, but Lord Derby repudiated the act. Finally, Britain proclaimed a protectorate over south-eastern New Guinea in November 1884 when Australian State governments agreed to find the administrative costs of $\$ 30,000$ yearly. Germany claimed the north-eastern part a month later.

In 1888, the first Administrator of British New Guinea was appointed and was responsible to the Queensland government.

On 4 September 1889 , the first doctor to live in British New Guinea arrived in Port Moresby in the person of Sir William Macgregor, the Administrator. Born in Aberdeenshire in 1846, he graduated from Aberdeen M.B. 1872 and M.D. 1874 and then studied in Berlin, Florence and Paris. After a year at the Glasgow Royal Infirmary and the Aberdeen asylum, he went to the Seychelles and in 1874 was surgeon of the Port Luis Hospital at Mauritius. He was Chief Medical Officer in Fiji from 1875 till 1888 and was Acting Governor and High Commissioner on several occasions. In New Guinea he explored widely and did his best to develop the people-he established the native police force and village constables but did little medicine. He was a remarkable man of great ability and strength who considered that he could do anything as well as or better than another man. He left New Guinea in 1899.

In German New Guinea there was at least one doctor in Finschhafen employed by the German 
New Guinea Company between 1885 and 1889. In 1901 Dr Robert Koch visited German New Guinea to set up some studies on malaria and other tropical diseases; he arranged for Dr Dempwolff to carry them on after he left. Dr W. Wendland, in 1902, wrote a report on malaria, dysentery and venereal disease, but there was no Government Hospital for him to work in. By 1907 there were two doctors in German New Guinea and the first private practitioner arrived in 1912. By 1913 there were six doctors, but they had not evoked the confidence of the native population; however, the Government and Mission doctors were interested in native health and established a type of medical orderly who did village health work after 3 months' training.

In June 1897, Dr J. A. Blayney, L.R.C.P. and R.C.S. (Edin.), L.F.P.S. (Edin.) 1894, became the second doctor in British New Guinea when he was appointed Resident Magistrate and Government Medical Officer, a not unusual dual appointment. When MacGregor left in 1899 he was appointed Chief Medical Officer, a somewhat empty title since he had no medical or para-medical assistance till 1901. His requests for two more medical officers were refused by the Colonial Office. He presented the first departmental medical report of a Chief Medical Officer in New Guinea; established a Medical Department consisting of a Chief Medical Officer in Port Moresby and a Medical Officer at Samarai, and was a member of the Executive and Legislative Councils and Board of Native Affairs.

In December 1899, Mr. Cecil Vaughan was appointed Acting Government Medical Officer for the Eastern Districts, and was stationed at Samarai. Though he was the only person available, his appointment was much questioned because he was 'not really a doctor'. He has gained a lot of experience in the Indian Medical Service and came to New Guinea as the manager of a company to exploit rubber on the Musa River but the project failed, so he accepted the appointment which he held till 1903.

Dr A. J. Craigen, M.B., was appointed Acting Chief Medical Officer when Dr Blayney went on leave in 1901 and Chief Medical Officer when Blayney resigned on his return from leave in 1902. In 2 years of office he established a native hospital for $\$ 200$ at Samarai and this was the first provision of medical services for the natives. A similar sum was made available later to build a native hospital in Port Moresby. A European hospital had been built at Samarai by public subscription but closed from lack of supporting funds, whilst the planned European hospital at Port Moresby could not be built because of shortage of tradesmen. The local gaol had been used since 1897 for medical emergencies.

In Samarai, the most populous European settle- ment, Dr J. Taylor Hancock became Government Medical Officer for the Eastern Division in 1903, dying there of fever in 1905, being cared for by his successor, Dr Robert Fleming Jones. Samarai itself was now relatively free from malaria due to the draining of the swamps by MacGregor as an antimalarial measure although the role of the mosquito was not yet recognized.

Dr Colin Coote-Simson, M.R.C.S., L.R.C.P. (London) 1898 was Chief Medical Officer in 1904-05, and Dr Noel Beaumont succeeded him in 1906 when Dr Walter M. Strong M.D. arrived as Assistant Resident Magistrate. By 1906 three European hospitals had been built, at Samarai, at Woodlark Island and at Port Moresby, and one additional Medical Officer had been appointed. The goldfields on Woodlark Island had been opened up in 1895 and Mr John Taaffe 'a gentleman of considerable skill in the treatment of tropical disease' had reported two epidemics of dysentery with considerable mortality: a hospital was a necessity for his patients. In Port Moresby the hospital was opened in 1906 but, lacking money, only Dr Beaumont lived in it and he reported that the four patients admitted during the year had occupied one of the two rooms allotted for patients. Field surveys had begun and data on disease prevalence and incidence began to accumulate but the real problems of native health and disease were still unknown. There were six doctors in the whole of New Guinea, British and German, from 1906 to 1910.

In 1906, hospitals were opened at Samarai and on Kiriwina Island in the Trobriand group for the treatment of venereal diseases which were said to be prevalent, though confusion between yaws and syphilis was common. The special hospital in the Trobriand Islands was put in the charge of Rayner Laming Bellamy, Magistrate and Medical Officer, whose contributions to the health of New Guinea have been described in detail by Professor R. H. Black. Bellamy was born in Staffordshire in 1874, started medicine at Cambridge and graduated B.A. in 1894, went to Edinburgh in 1897 but ceased his course in 1900 without taking his finals. A transient stage career was followed by newspaper work in New Zealand and he then went to New Guinea where he became Assistant Magistrate at Kokoda in 1903. He became Resident Magistrate and Medical Officer in the Trobriands in 1905 and introduced the first census and register of births and deaths, sought his cases on medical patrol and was successful in the campaign against venereal disease. Enlisting in the Army in 1915 he served in France, took 6 months leave in 1917 and obtained his L.R.C.P. and R.C.S. (Edin.) and L.R.C.P.S. (Glasgow). He returned to New Guinea in 1918 and worked in most divisions till 1925 when he went to England 
before taking the Australian Diploma in Tropical Medicine at the age of 52 years. He returned to the Trobriands and then spent his last 6 years in the Territory as a Travelling Government Medical Officer in Eastern Papua. He contributed in many ways to public health by his epidemiological studies of leprosy, malaria and dysentery, by introducing vital statistics, by planting coconuts to improve food supplies and by his efforts to persuade natives to seek medical help rather than to rely on the sorcerers.

Negotiations to transfer British New Guinea to Australia began in 1898 but it was not until 1905 that the Papua Act did this and gave the Territory its name, gave the Governor General of Australia the authority to appoint a Lieutenant Governor, and provided for the establishment of Executive and Legislative Councils. Papua referred to the southeastern part of the New Guinea mainland and the islands off its eastern tip.

In September 1914, Australian troops occupied German New Guinea and Captain B. C. A. Pockley, a young Sydney graduate, became the first Australian doctor killed in the war. He was shot in the spine after dressing a German NCO's hand in the attack on the Radio Station at Rabaul and giving his brassard to a soldier to act as a stretcher-bearer.

In 1919, the Australian Prime Minister, W. M. Hughes, at the Peace Conference, obtained the German part of New Guinea as a Mandated Australian Territory, and an administration separate from Papua was set up.

In 1928 a Bill was introduced into the Australian Parliament to create Executive and Legislative Councils into the Mandated Territory, but Parliament dissolved and the Act did not come into being till 1933. General Evan Alexander Wisdom was the first Australian Administrator, from 1920 to 1930, and on retirement was criticized by the Sydney Morning Herald on the grounds that 'he measured everything according to a narrow conception of what was good for the natives'!

The amalgamation of Papua and the Mandated Territory was considered in 1919 but was rejected, as were the notions of a combined civil service in 1934 and of a combined administration in 1939. It is important to realize that the official languages for the two areas were different; police Motu in Papua and Pidgin in the Mandated Territory. In 1942 , the administrative services were amalgamated but the Japanese invasion occurred and civil control was not restored until 1946 when the Trustee Agreement for New Guinea was approved by the General Assembly of the United Nations.

By about 1908 coconut and rubber plantations had developed rapidly and by 1910-12 dysentery was prevalent on plantations and in villages: as
Lambert put it, 'the isolated white man having lower sanitary standards than the primitive native'. Disastrous epidemics occurred in the goldfields. At Lakekamu, for example, in $1910 \mathrm{Dr}$ Julius G. Streeter reported a death rate of $35 \%$ in the native hospital and Dr C. C. Simson, Chief Medical Officer, reported five European deaths, and that 255 of the 600 natives there had died in 5 months. Simson further commented that epidemic pertussis and dysentery were uniformly fatal in children.

In 1912, Dr W. M. Strong, now Chief Medical Officer, appointed a Governor Travelling Medical Officer to travel about the Territory and to deal with epidemics: this type of appointment continued for the next 30 years. These officers took three native helpers with them and this led to the development of Native Medical Assistants who became very proficient at giving intravenous injections for yaws even though they might be unable to read or write. In 1922 a definite policy of training Native Medical Assistants to provide health in villages was implemented - they treated yaws and tinea and provided simple medical and surgical treatment. By 1930 they were making independent patrols and reporting in English.

In late 1932, Dr W. M. Strong realized that the usefulness of Native Medical Assistants could be increased if their medical education was increased beyond that being given by the local doctors and European Medical Assistants. He arranged with the Commonwealth Director General of Health for twelve Papuans to come to the School of Public Health and Tropical Medicine in Sydney. They stayed for 6 months and attended courses in the subjects of first and second year medicine. In March 1934, they returned to Papua and were sent over a wide area, usually to work in the supervision of a Resident Magistrate. Later a larger second group was sent.

By 1936 there were fifty Native Medical Assistants, many working in villages supervised by the four European Medical Assistants who were under the Chief Medical Officer. In the Mandated Territory there were ten native hospitals in 1922 and thirty European Medical Assistants by 1926. The Germans had introduced the system of medical 'tul-tuls', doctor boys, called 'lik-lik' doctors in Papua, who were medical orderlies in the villages. There were many of them in 1939 doing excellent work.

The Missions have played a significant role in the provision of medical care for the native population; the London Missionary Society opened a hospital in Port Moresby in 1924, the Methodists (Dr Judkins) at Salamaua in 1925, the Anglicans (Dr Gill) at Gona in 1926. In 1930 the Missions were asked to take over Infant Welfare and were subsidized for this purpose. 
Dr Honman was the Chief Medical Officer in the Mandated Territory in 1922 and was succeeded by Dr Raphael Cilento, 1923, who stepped down from the Directorship of the Townsville School of Tropical Medicine. Cilento increased the number of Travelling Medical Officers and, in 1926, arranged for medical officers from the Mandated Territory to have training in Townsville.

Dr Edward Thomas Brennan, D.S.O., M.C., M.B., B.S. (Melb.) 1909, succeeded Cilento in 1928 and remained in charge until the Japanese invasion in 1942. He was the most experienced Australian Tropical Administrator and acquired a good reputation not only in the medical service and administration but also amongst the native peoples with whom he worked, by his human understanding.

At the conclusion of the 1939-46 war, four Papuan students were given intensive secondary schooling prior to being sent to Fiji for training as Native Medical Practitioners and the first of them arrived back in 1952. Numbers increased slowly and there were thirteen Fijian graduates by 1964 .

In 1946, the position of Director of Public Health was created and Dr John Thompson Gunther, M.B., B.S. (Sydney) 1935 was appointed to it. By 1949 there were only twenty-six doctors in the Territory so Dr Gunther went to Europe to recruit Medical Officers and, as a result, thirty-seven European graduates arrived in 1949 and 1950. Others came later, for example after the Hungarian revolt in 1956, and these foreign graduates have contributed greatly to health in New Guinea. After 1954 more Australian graduates came and in 1958 the first Cadet Medical Officers started work. In 1957, Dr Gunther became Assistant Administrator for the Territory and, in 1966, first Vice-Chancellor of the University of Papua and New Guinea in the formation of which he has played a major role.

The Papuan Medical College was established in 1958 , becoming the first truly tertiary educational institution in Papua and New Guinea to provide a course of training for Assistant Medical Practitioners. After a preliminary year students entered a 5-year course based on the Australian pattern though the standard was necessarily lower. Consultants were brought to the College from Australia each year for teaching and examining and to advise on standards and curriculum.

The first three Assistant Medical Practitioners graduated in 1964 and then went to the General Hospital for 2 years training. Since then another twenty-four students have graduated.

In 1962-63 a 3-year course of training for Medical Assistants was introduced with the first and third years at the Papuan Medical College: courses of training for radiographers, laboratory technicians, health inspectors and for physiotherapy technicians have been introduced since 1965. The Rural Health Training Centre was planned in 1966.

A major difficulty which makes the teaching of students less effective than in many other countries is that of language. There are probably as many as 500 distinct languages in the Territory. All training is carried out in the wards of the Port Moresby hospital and students from, say, Rabaul, may be unable to talk to any of the patients who speak many unrelated languages.

In 1966, the University of Papua and New Guinea's preliminary year became a pre-entry requirement for the Papuan Medical College, and thirteen students were able to enter first year medicine in 1968.

After 2 years of discussion, the Administration, in 1969, invited the University of Papua and New Guinea to submit detailed plans for the establishment of a Faculty of Medicine and Dr Ian Maddocks, Dean of the Papuan Medical School, Dr Roy F. R. Scragg, Director of Public Health, and Dr John Gunther saw the fruits of their labours. A first-class course of training has been proposed to provide medical graduates especially fitted to deal with the problems of providing health for the people of New Guinea. Special emphasis is to be laid on rural medicine, on preventive health and on sociological medicine. The first graduates are expected in 1972 and the graduation of Assistant Medical Practitioners will cease.

The total number of medical practitioners in 1969 is about 250 , of whom 180 are overseas graduates. It is estimated that this will rise to about 500 in 1977 or 1978 , of whom only about 105 will be from overseas, the rest being Assistant Medical Officers and Territory graduates. This will mean one Medical Officer for each 6300 persons in the country.

\section{References}

BADGER, G.P. (ed.) (1863) The travels of Ludovico di Varthema, 32, The Hakluyt, Society, London.

BeOGLEHOLE, J.C. (ed.) (1962) The Endeavour Journal of Joseph Banks. Angus \& Robertson, Sydney.

BLACK, R.H. (1957) Dr Bellamy of Papua. Medical Journal of Australia, ii, 189-197, 232-238, 279-284.

BougAinville, L. DE (1772) (trans. by Forster, J.R. 1967) $A$ voyage round the world. Bibliotheca Australiana, 12. Israel, Amsterdam.

BRENNAN, E.T. (1954) Obituary of. Medical Journal of Australia, i, 919.

British New Guinea AnNual Reports for the years 18971905, Commonwealth of Australia, Government Printer, Victoria.

BURNEY (1967) Chronological history of voyages and discoveries in the South Seas, Vol. 1. Bibliotheca Australiana, 3-7. Israel, Amsterdam.

Butler, A.G. (1940) Official history of Australian Army Medical Services, 1914-1918, Vol. 1. Australian War Memorial, Canberra.

Chalmers, J. (1885) Work and Adventure in New Guinea. The Religious Tract Society, London. 
DalRymple, A. (1967) A historical collection of the voyages and discoveries in the South Pacific Ocean. Bibliotheca Australiana, 11, Israel, Amsterdam.

DUMONT D'URVILLE, J.S.C. (1951) Translation of Voyage de l'Astrolabe. Wingfield Press, Wellington.

Dunmore, J. (1965) French Explorers in the Pacific, Vol. 1, the 18th century. Clarendon Press, Oxford.

Grant, B. (1964) Indonesia. Melbourne University Press, Melbourne.

GreenOP, F.S. (1944) Who travels alone. Murray, Sydney.

HuXLEY, J. (ed.) (1935) T.H. Huxley's Diary of the Voyage of H.M.S. Rattlesnake. Chatto \& Windus, London.

LAMBERT, S.M. (1928) Medical conditions in the South Pacific. Medical Journal of Australia, ii, 362.

LAWES, W.B. (1887) The effect of the climate of New Guinea upon exotic races of Port Moresby, New Guinea. Australian Medical Gazette, 6, 185.

MaIR, L.P. (1948) Australia in New Guinea. Christophers, London.

Markham, C. (trans. \& ed.) (1904) The Voyages of Pedro Fernandez de Quiros, 1595-1606, Vol. II, Series II, Vol. XV. Hakluyt Society, London.

Monkton, C.A.W. (1921) Some Experiences of a New Guinea Resident Magistrate. John Lane, London.

Murray, J.H.P. (1910) Papua-Progress of the Territory. Report of the Lt. Governor J.H.P. Murray to the Hon. Minister for External Affairs.

Murray, J.H.P. (1912) Papua or British New Guinea. Fisher Unwin, London.

Newland, H.S. (1947) The Archibald Watson Memorial Lecture. Medical Journal of Australia, ii, 381.
Niau, J.H. (1956) The Phantom Paradise: The Story of the Expedition of the Marquis de Ray. Angus \& Robertson, Sydney.

PAPUA, Annual Reports for the years 1906-1907, 1909-1910, 1912-1915, 1958-1959, Government of the Commonwealth of Australia, Government Printer, Victoria.

Pearl, C. (1967) Morrison of Peking. Angus \& Robertson, Sydney.

SCRAGG, R.F.R. (1964) The medical profession in Papua and New Guinea, 1884-1984, Papua \& New Guinea Scientific Society Annual Report and Proceedings. 16, 22.

Sharp, A. (1963) The Discovery of Australia. Clarendon Press, Oxford.

Souter, G. (1965) New Guinea, the Last Unknown. 3rd edn. Angus \& Robertson, Sydney.

STEVENS, H.N. (ed.) (1930) New light on the discovery of Australia as revealed by the journal of Captain Don Diego de Prado y Tovar. Series II, Vol. LXIV. Hakluyt Society, London.

STroNG, W.M. (1935) The medical education of the Papuan natives. Medical Journal of Australia, i, 305.

Territory OF Papua AND New Guinea, Department of Public Health Annual Reports, 1960-61 and 1968-69.

Wallis, H. (ed.) (1965) Carteret's Voyage Round the World, 1766-69, Series II, Vol. CXXIV. Hakluyt Society, London.

Williamson, J.A. (ed.) (1939) Dampier's 'A Voyage to New Holland'. Argonaut, London.

Wood, G.A. (1922) The Discovery of Australia. MacMillan, London.

Wurm, S.A. (1966-67) Papua-New Guinea nationhood: The problem of a national language. Journal of the Papua and New Guinea Society, 1, 7. 